\title{
Fish Community Structure and Environmental Correlates in Nepal's Andhi Khola, Province No. 4, Syangja
}

\author{
JASH HANG LIMBU ${ }^{* 1}$, BISHNU BHURTEL ${ }^{1}$, ASHIM ADHIKARI ${ }^{2}$, PUNAM GC $^{2}$, MANIKA $^{2}$ \\ MAHARJAN $^{2} \&$ SUSANA SUNUWAR ${ }^{2}$
}

${ }^{1}$ DAV College, Faculty of Science and Humanities, Department of Microbiology, Tribhuvan University, Dhobighat, Lalitpur, Nepal; ${ }^{2}$ Central Department of Zoology, Tribhuvan University, Kirtipur, Kathmandu, Nepal

*Corresponding author: limbujash@gmail.com

Received: 19 August $2020 \quad$ Accepted: 13 October $2020 \quad$ Published: 31 December 2020

\begin{abstract}
The study of correlations between fish diversity, environmental variables and fish habitat aspects at different space and time scales of Nepal's rivers and streams is scanty. This study investigated spatial and temporal patterns of fish assemblage structure in Nepal's Andhi Khola. The field survey was conducted from September 2018 to May 2019 and the fishes were sampled from three sites using a medium size cast net of mesh size ranging from 1.5 to $2.5 \mathrm{~cm}$ and gill net having 2-3 cm mesh size, 30-35 feet length and 3-4 feet width, with the help of local fisher man. A total of 907 individuals representing 15 species belonged to four orders, six families and 11 genera were recorded during the study time. To detect the feasible relationships between fish community structure and environmental variables, we executed a Canonical Correspondence Analysis (CCA). Based on similarity percentage (SIMPER) analysis, the major contributing species are Barilius barila (26.15\%), Barilius vagra (20.48\%), Mastacembelus armatus (8.04\%), Puntius terio $(6.64 \%)$, and Barilius bendelisis (5.94\%). One-way analysis similarity (ANOSIM) tried out for both time and space variations in fish community structure suggested that there was a significant difference in temporal variation $(R$ $=0.794, P=0.0037)$ but no significant difference in spatial variation $(R=-0.18, P=0.923)$. Results from the Canonical Correspondence Analysis (CCA) vindicated that dissolved oxygen, free carbon-dioxide and total hardness were the principle physio-chemical correlates of fish assemblage structure. One-way analysis of similarity (ANOSIM) on the Non-metric Multidimensional Scaling (NMDS) showed significant difference between spring, autumn and winter season but no significant difference was found in spatial variation. The extraction and transportation of boulders, cobbles, pebbles, sand mining, haphazard ongoing road development and dam construction for the irrigation without fish ladders were found to be existing threats to the fish diversity of Andhi Khola.
\end{abstract}

Keywords: Fish assemblage, multivariate analysis, rivers, spatio-temporal, streams

Copyright: This is an open access article distributed under the terms of the CC-BY-NC-SA (Creative Commons Attribution-Non Commercial-ShareAlike 4.0 International License) which permits unrestricted use, distribution, and reproduction in any medium, for non-commercial purposes, provided the original work of the author(s) is properly cited.

\section{INTRODUCTION}

The recognition of dissimilarity patterns in rivulet residence fish community down with possible contributory causes is a main issue in rivulet ecology (Matthews, 1998). Numerous research has shown that factors affecting fish community require the physiochemical environment, which is spatially diversified and seasonally differ, and living interactions such as competition and predation (Gorman, 1988; Harvey \& Stewart, 1991; Grossman et al., 1998). Among different environmental parameters, the dissolved oxygen (DO) and temperature are most important for fish and highly effect on fish diversity and distribution. The amount of dissolved oxygen and temperature are higher in summer than winter due to which fish diversity is higher in summer (Adoni, 1985). Along the headwater-downstream longitudinal gradient, fish community often incident increase in species richness and abundance, mostly evolving from an increase in habitat complication and diversity variation in the rate of fish migration and disappearance (Matthews, 1986). However, an asymptote or reduce in species richness is also noticed in the lower reaches of some creeks, which could be due to greater pollution levels (Oberdorff, 1993). Small brooks and creeks also indicate an 
ecological slope, along which upstream structures are relatively diversified but downstream assemblages are comparatively stable.

This is related with the common model of upstream environments being naturally variable and skeletally simple while downstream environments are the opposite. Riparian or creek fishes of the developing world have accepted to differentecological stresses affecting fish community structure of that habitat (Grossman, 1990). However, alliance between fishes and their environments play an imperative role for controlling and economizing of riparian species where any modification of it can lead to modify in their population (Kadye \& Moyo, 2007). The goal of this study was to characterize fish community patterns in space and time and to investigate fish community structure relationships with the environmental parameters of Andhi Khola.

\section{MATERIALS AND METHODS}

\section{Study Area}

Andhi Khola (Figure 1) is a glacier-fed permanent river located in western region of Nepal. It is a main river of Syangja district and has its origin from Dahare hill, southeast from Karkineta. It is estimated to be $96 \mathrm{~km}$ long with a catchment area of $195 \mathrm{~km}^{2}$, which finally drain to Kali Gandaki. It is located between $27^{\circ} 50^{\prime} \mathrm{N}$ and $28^{\circ} 10^{\prime} \mathrm{N}$ latitude, and $83^{\circ} 50^{\prime} \mathrm{E}$ and $84^{\circ} 50^{\prime} \mathrm{E}$ longitude with altitudes from 540 to $1020 \mathrm{~m}$ above sea level, covering an area of about $200 \mathrm{~km}^{2}$. It flows southwards and joins Kaligandaki River near Mirmi, Syanjaa. The river basin is used for irrigation, drinking water supply, recreation and micro-hydropower generation.

\section{Sampling Sites}

For the present investigation, the field work was conducted from September 2018 to May 2019 with three seasons: autumn (September, October and November), winter (December, January and February), and spring (March, April and May). Fishes were sampled from three sites using a medium size cast net of mesh size ranging from 1.5 to $2.5 \mathrm{~cm}$ and Gill net having $2-3 \mathrm{~cm}$ mesh size, 30 35 feet length and 3-4 feet width, with the help of local fisher man. These fishing gears were operated within $500 \mathrm{~m}$ area of each site for 2 hours in each station at 7-9 am. Total 40 hurls were made for cast net and 4 hauls for gill net to catch fishes.

For estimation of abundance of fishes, two pass removal methods (Seber, 1967) were used. Each removal pass includes moving first upstream/river then downstream/river within a pre-determined length $(500 \mathrm{~m})$ with equal effort 30 minutes for each pass at each site of the river. The number of fish species in the samples and the number of individuals in each species were counted and the local name of fish species was taken from local fishermen. The collected fish samples were photographed and were preserved in $10 \%$ formalin solution in plastic jars and brought to Central Department of Zoology (CDZ) lab, Tribhuvan University, Kirtipur, Kathmandu, Nepal for further identification. The identification was done by using standard taxonomic references (Talwar \& Jhingran, 1991; Jayaram, 2010).

\section{Analysis of Environmental Variables}

Water samples of Andhi Khola were collected during morning time (7:00 am to 9:00 am) and analyzed once every three months during field visit. Water temperature was appraised with a mercury thermometer by putting it down in the water at a depth of one feet. The $\mathrm{pH}$ was measured by using a calibrated $\mathrm{pH}$ meter (HANNA Instrument, HI 98107). The dissolved oxygen was measured by the Winkler titra-metric method. The sample of water from every sampling site was collected in $300 \mathrm{ml}$ BOD bottle without bubbling. Then, $2 \mathrm{ml}$ of $\mathrm{MnSO}_{4}$ and $2 \mathrm{ml}$ of $\mathrm{KI}$ was poured gently from the side of the bottle, then this mixture was shaken well so as to complete the reaction and the sample was left half an hour for the settlement of the precipitates. About $2 \mathrm{ml}$ of concentrated $\mathrm{H}_{2} \mathrm{SO}_{4}$ was added in the solution to dissolve the brown precipitate settled at the bottom. Sodium thiosulphate $(0.025 \mathrm{~N})$ was taken in the burette rinsed by the solution for titration. About $50 \mathrm{ml}$ of the mixture was taken on the conical flask and one or two drips of starch solution were added as indicator. Then, the titration was done against the sodium thiosulphate solution, till the solution become colourless. Total hardness (mg/l) was determined using EDTA titrametric method.

\section{Data Analysis}

The correlation between fish community structure 


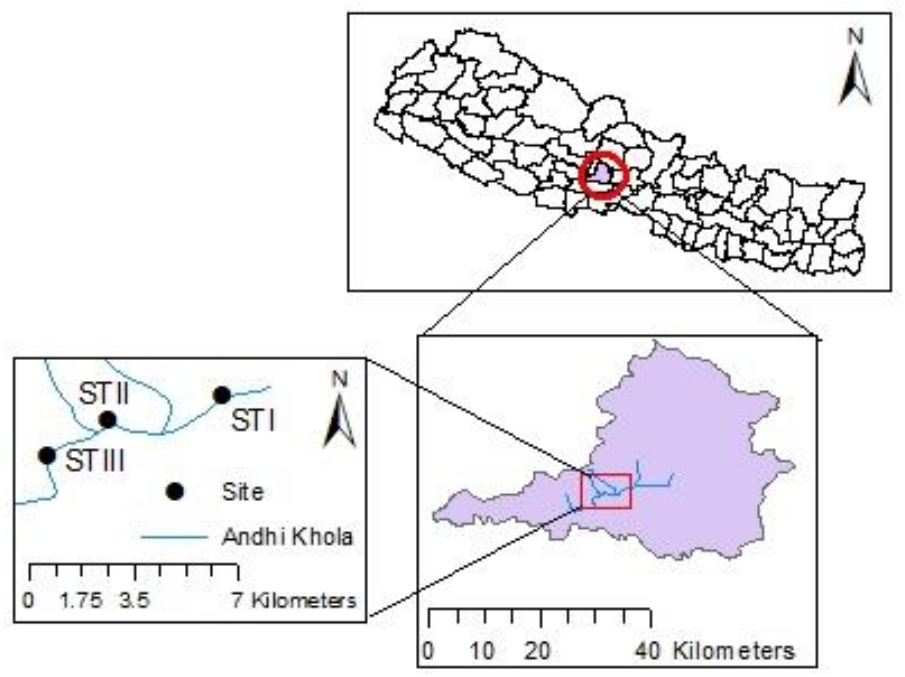

Figure 1. Map of study area showing Andhi Khola

and environmental variables was first done by selection of appropriate tests a Detrended correspondence analysis (DCA). The axis length and eigen value acquired from DCA suggested that the linear model of Canonical Correspondence Analaysis (CCA) was more applicable. Therefore, a direct multivariate ordination method (TerBraak, 1986) based on a linear response of species to environmental gradients was applied by using vegan library in $\mathrm{R}$ (Oksanen, 2015). One-way analysis of similarity (ANOSIM) was used to conclude the significance of space and time variation of fish community structure (Clarke, 1993). Similarity percentages analysis (SIMPER) was executed to notice the percentage of similarity in temporal scale (Clarke, 1993). The relationships amongst assemblages from each site and season are graphically represented using pvcluster analysis and non-metric Multi-Dimensional Scaling analysis (NMDS) (Clarke \& Warwick, 2001).

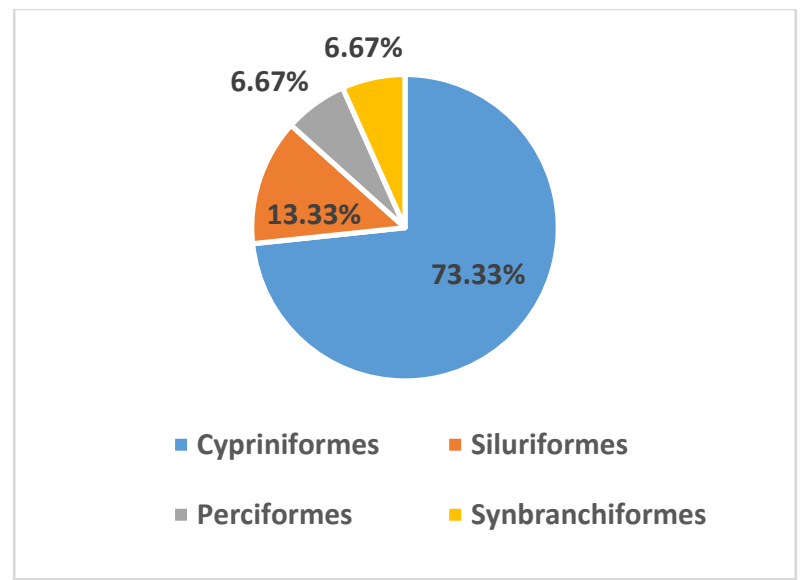

Figure 2. Order wise percentage compositions of fishes of Andhi Khola

\section{RESULTS}

A total of 907 individuals representing 15 species belonged to four orders, six families and 11 genera were recorded during the study period (Table 1). The order Cypriniformes was found to be dominated order which comprised $73.33 \%$ followed by Siluriformes $13.33 \%$, Synbranchiformes $6.67 \%$ and Perciformes $6.67 \%$ (Figure 2). The Cyprinidae was the most speciesrich family ( 5 genera and 8 species) followed by Cobitidae (2 genera and 3 species), Heteropneustidae, Sisoridae, Mastacembelidae and Channidae with single genus and species (Table 1, Figure 3).

The highest number of individuals was reported from station II and in spring season, whereas the lowest was found from station I and in autumn season (Table 2 ). Based on similarity percentage

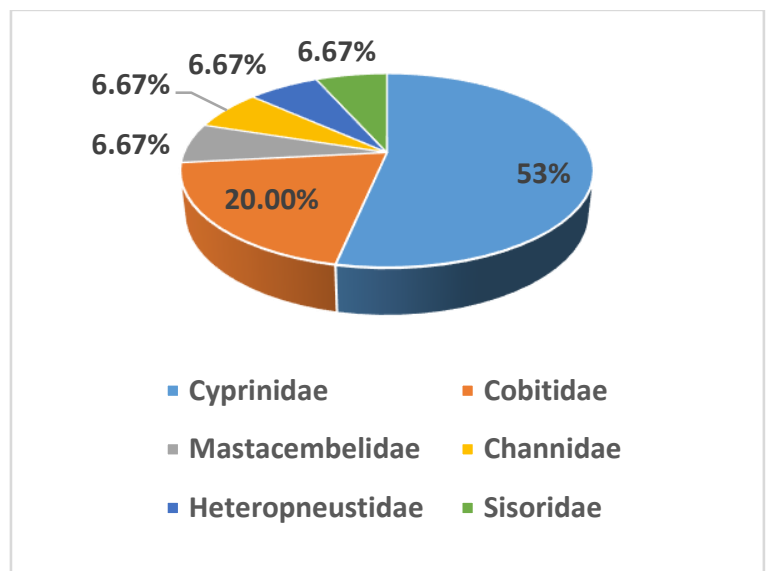

Figure 3. Family wise percentage compositions of fishes of Andhi Khola 
Table 1. List of fishes collected from AndhiKhola

\begin{tabular}{|c|c|c|}
\hline Order & Family & Species \\
\hline \multirow{11}{*}{ Cypriniformes } & \multirow{8}{*}{ Cyprinidae } & Barilius barila (Hamilton-Buchanan, 1822) \\
\hline & & Barilius vagra (Hamilton-Buchanan, 1822) \\
\hline & & Barilius bendelisis (Hamilton-Buchanan, 1822) \\
\hline & & Neolissochilus hexagonolepis (MCclelland, 1839) \\
\hline & & Puntius terio (Hmailton, 1822) \\
\hline & & Schizothorax plagiostomus Hackel, 1838 \\
\hline & & Garra mullya (Hamilton, 1822) \\
\hline & & Garra rupecula (MCclelland, 1839) \\
\hline & & Schistura horai (Menon, 1952) \\
\hline & Cobitidae & Schistura sovana (Hamilton, 1822) \\
\hline & & Lepidocephalus guntea (Hmailton, 1822) \\
\hline \multirow{2}{*}{ Siluriformes } & Heteropneustidae & Heteropneustes fossilis (Bloch, 1794) \\
\hline & Sisoridae & Glyptothorax trilineatus Blyth, 1860 \\
\hline Synbranchiformes & Mastacembelidae & Mastacembelus armatus (Lacepede, 1800) \\
\hline Perciformes & Channidae & Channa punctatus (Bloch, 1793) \\
\hline
\end{tabular}

Table 2. Spatial and temporal species abundance and distribution

\begin{tabular}{|c|c|c|c|c|c|c|c|c|}
\hline Code & Species & Total & Station I & Station II & StationIII & Aut & Win & Spr \\
\hline C1 & Barilius barila & 320 & 87 & 133 & 100 & 58 & 119 & 143 \\
\hline $\mathrm{C} 2$ & Barilius vagra & 248 & 67 & 98 & 83 & 40 & 98 & 110 \\
\hline C3 & Barilius bendelisis & 33 & 13 & 14 & 6 & 0 & 15 & 18 \\
\hline $\mathrm{C} 4$ & $\begin{array}{c}\text { Lepidocephalus } \\
\text { guntea }\end{array}$ & 7 & 2 & 5 & 0 & 0 & 0 & 7 \\
\hline C5 & Garra rupecula & 32 & 11 & 14 & 7 & 6 & 5 & 21 \\
\hline C6 & Garra mullya & 36 & 16 & 13 & 7 & 11 & 8 & 17 \\
\hline C7 & $\begin{array}{l}\text { Neolissochilus } \\
\text { hexagonolepis }\end{array}$ & 26 & 12 & 9 & 5 & 0 & 11 & 15 \\
\hline $\mathrm{C} 8$ & Puntius terio & 32 & 5 & 16 & 11 & 3 & 2 & 27 \\
\hline C9 & $\begin{array}{l}\text { Glyptothorax } \\
\text { trilineatus }\end{array}$ & 25 & 7 & 13 & 5 & 1 & 10 & 14 \\
\hline $\mathrm{C} 10$ & Schistura horai & 21 & 8 & 9 & 4 & 10 & 3 & 8 \\
\hline $\mathrm{C} 11$ & Schistura savona & 25 & 7 & 10 & 8 & 6 & 3 & 16 \\
\hline $\mathrm{C} 12$ & $\begin{array}{l}\text { Heteropneustes } \\
\text { fossilis }\end{array}$ & 2 & 0 & 0 & 2 & 0 & 0 & 2 \\
\hline $\mathrm{C} 13$ & Channa puctatus & 13 & 0 & 5 & 8 & 13 & 0 & 0 \\
\hline $\mathrm{C} 14$ & $\begin{array}{l}\text { Schizothorax } \\
\text { plagiostomus }\end{array}$ & 22 & 5 & 12 & 5 & 6 & 16 & 0 \\
\hline $\mathrm{C} 15$ & $\begin{array}{c}\text { Mastacembelus } \\
\text { armatus }\end{array}$ & 65 & 14 & 29 & 22 & 11 & 13 & 41 \\
\hline Total & & 907 & 254 & 380 & 273 & 165 & 303 & 439 \\
\hline
\end{tabular}

Table 3. Average similarity and discriminating fish using SIMPER analysis

\begin{tabular}{cccccc}
\hline Code & Species & $\begin{array}{c}\text { Contribution } \\
(\boldsymbol{\%})\end{array}$ & Code & Species & $\begin{array}{c}\text { Contribution } \\
(\boldsymbol{\%})\end{array}$ \\
\hline C1 & Barilius barila & 26.15 & $\mathrm{C} 9$ & Glyptothorax trilineatus & 4.007 \\
C2 & Barilius vagra & 20.48 & $\mathrm{C} 13$ & Channa puctatus & 4.004 \\
C15 & Mastacembelus armatus & 8.04 & $\mathrm{C} 11$ & Schistura savona & 3.502 \\
C8 & Puntius terio & 6.645 & $\mathrm{C} 6$ & Garra mullya & 2.96 \\
C3 & Barilius bendelisis & 5.94 & $\mathrm{C} 10$ & Schistura horai & 2.652 \\
C7 & Neolissochilus hexagonolepis & 4.86 & $\mathrm{C} 4$ & Lepidocephalus guntea & 1.651 \\
C14 & Schizothorax plagiostomus & 4.29 & $\mathrm{C} 12$ & Heteropneustes fossilis & 0.5432 \\
C5 & Garra rupecula & 4.25 & & & \\
\hline
\end{tabular}


(SIMPER) analysis the major contributing species were Barilius barila (26.15\%), Barilius vagra (20.48\%), Mastacembelus armatus (8.04\%), Puntius terio (6.64\%), and Barilius bendelisis (5.94\%) (Table 3). One-way analysis similarity (ANOSIM) tried out for both space and time variations in fish community suggested that there was a significant difference in temporal variation ( $R=0.794, P=0.0037$ ) but there was no significant difference in spatial variation $(R=-0.18, P=$ $0.923)$.

\section{Correlation between Fish Assemblage Structure and Environmental Variables}

The Canonical correspondence (CCA) analysis showed that the fish species of Barilius bendelisis (C3), Gara mullayu (C6), Neolissochilus hexagonolepis (C7) and Glyptothorax trilineatus (C9) were positively linked to $\mathrm{pH}$ but negatively connected to total hardness. Fish species of Barilius barila (C1), Barilius vagra (C2) and Schizothorax plagiostomus (C14) showed positive

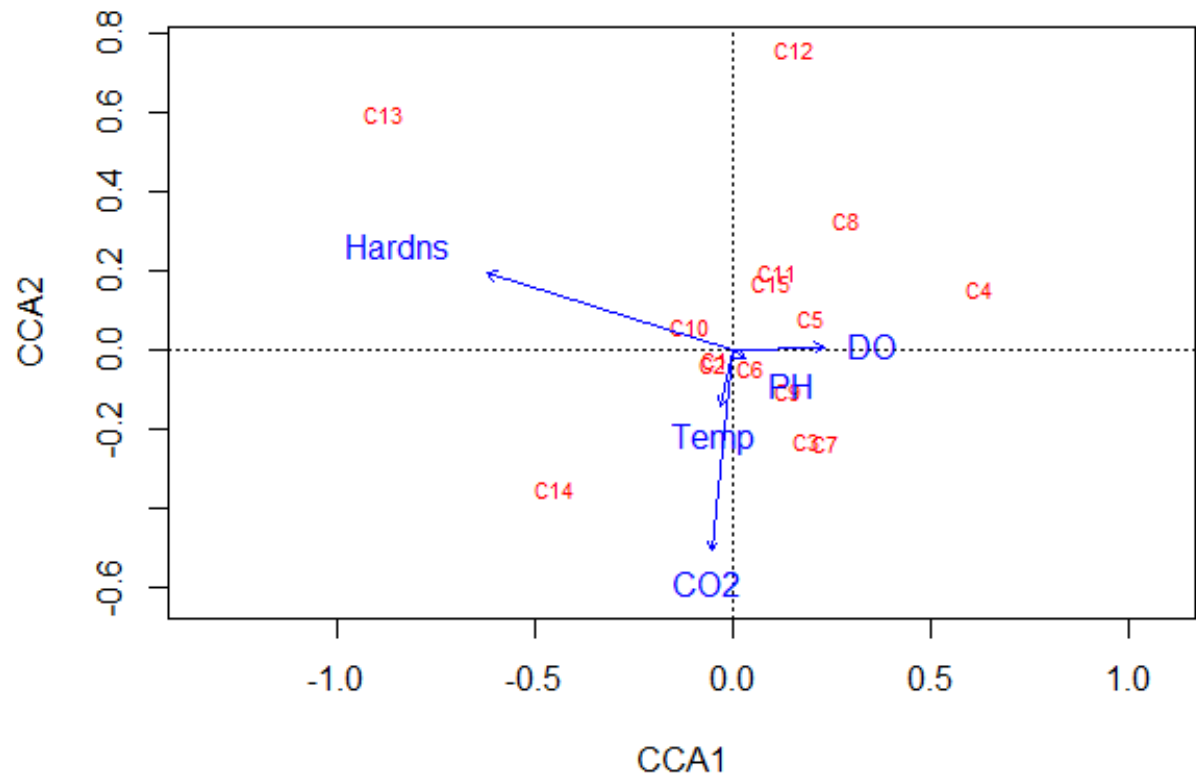

Figure 4. Canonical Correspondence Analysis (CCA) ordination of fish assemblages and environmental variables of AndhiKhola $\left(\right.$ Hardns $=$ hardness, $\mathrm{DO}=$ dissolved oxygen, Temp $=$ water temperature and $\mathrm{CO}_{2}=$ free carbon-dioxide for species code, please refer Table 1)
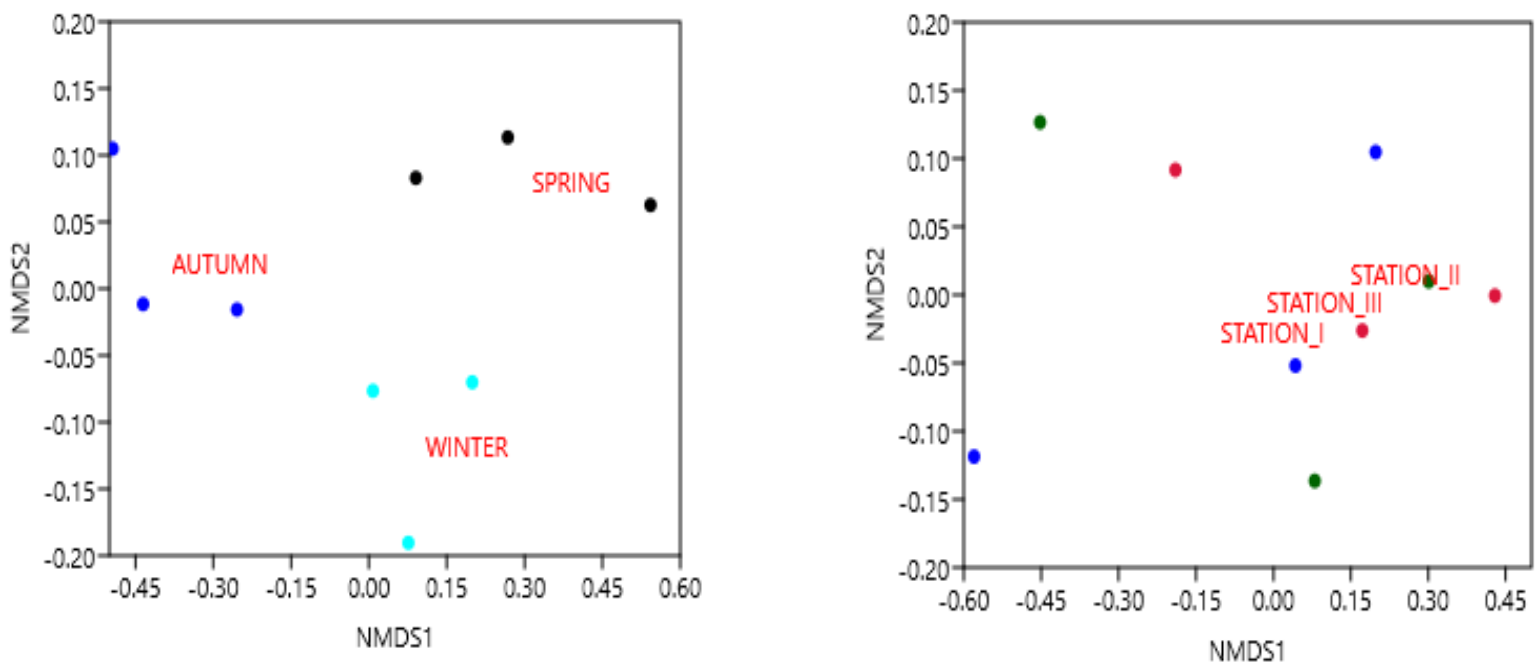

Figure 5. (a) NMDS ordination of temporal variation of fish assemblage in Andhi Khola, (b) NMDS ordination of spatial variation of fish assemblage in Andhi Khola 
relation with the water temperature and free carbon-dioxide. Fish species of Schistura horai (C10) and Channa punctatus (C13) were positively related to total hardness but negatively related to $\mathrm{pH}$. In contrast, fish species of Lepidocephalus guntea (C4), Garra rupecula (C5), Puntius terio (C8), Schistura Savona (C11), Heteropneustes fossilis (C12) and Mastacembelus armatus (C15) were positively associated with DO but negatively linked to water temperature and free carbondioxide (Figure 4). One-way analysis of similarity (ANOSIM) on the NMDS showed differences in species between spring, autumn and winter season but no significance difference was found in spatial variation (Figure 5a and $b$ ).

\section{DISCUSSION}

A total of 15 fish species were reported during the study period. Among them, similarity percentage (SIMPER) analysis indicated that, the fish species of Barilius barila, Barilius vagra, Mastacembelus armatus, Puntius terio, Barilius bendelisis, Neolissochilus hexagonolepis, Schizothorax plagiostomus, Garra rupecula, Glyptothorax trilineatus, Channa puctatus, Schistura Savona, Garra mullya, Schistura horai, and Lepidocephalus guntea, each contributing more than $1 \%$ of the total fish composition. From Andhi Khola, the Cypriniformes was recorded as a dominant order which comprised $73.33 \%$ of the total fish composition. This is closer to the findings of Edds (1986), Limbu and Gupta (2018), Limbu et al. (2018), Limbu et al. (2019a), Limbu et al. (2019b) and Limbu et al. (2019c). Nelson (2007) also indicated that the majority of the fishes from the river fall under the order Cypriniformes, this is the huge order of freshwater fishes which includes 2,422 species.

The Cyprinidae was recorded as a most species rich family with 8 species. The majority of the previous literature also showed, family Cyprinidae is the species rich family (Shrestha et al., 2009; Limbu et al., 2019c; Limbu et al., 2018, Limbu et al., 2019b and Subba et al., 2017; Pokharel, 2018; Oli, 2016). One-way analysis similarity (ANOSIM) try out for both space and time variations in fish community structure suggested that there was a significant difference in temporal variation $(R=0.794, P=0.0037)$ but no significant difference was observed in spatial variation $(R=$ $0.18, P=0.923$ ) which is inconsistent with the
Effects of environmental parameters on species distributions were checked by Canonical Correspondence (CCA) analysis. Species detected close by the genesis either do not depict a powerful association to any of the parameters or are found at average values of environmental parameters (Marshall, 1998). In the present study, dissolved oxygen, hardness, and free carbon-dioxide were found to be an important parameter to shape the fish community structure of Andhi Khola. Water temperature (Kadye et al., 2007) and dissolved oxygen (Limbu et al., 2019b) have already been shown to affect the fish community. Besides these, current velocity (Yu \& Lee, 2002), depth (Vlach et al., 2005; Kadye et al., 2007), width (Gerhard et al., 2004), substrate (Vlach et al., 2005), altitude (Magalhaes et al., 2002), conductivity (Yu \& Lee, 2002) and climate (Magalhaes et al., 2002) have all been also shown to influence fish community structure. The fish species of Barilius barila, Barilius vagra, Barilius bendelisis, and Mastacembelus armatus were ubiquitously found whereas Lepidocephalus guntae and Heteropneustes fossilis were sporadically found. Moreover, Channa sps, Schizothoraxsps, Lepidocephalus guntae and Heteropneustes fossilis have been declining their number from Nepal's rivers and streams. According to local fishermen, fish species of Channa stewartii, Macrognathus pancalus, Garra sps and Puntius sps have been severely depleted from Andhi Khola and were not found in our collection too. It might be due to the anthropogenic impacts (habitat destruction, electro-fishing, ongoing hydro-project development, haphazard road development, urbanization and dam construction), and climate change. Sand mining and extraction of boulders, cobbles and pebbles are frequent in this river. So, we concluded that these activities are responsible for declining the fish diversity of Andhi Khola. Therefore, for the better monitor, management and conservation of Nepal's indigenous fish species, habitat rehabilitation, and construction of fish ladders/passage are necessarily needed. Moreover, extraction and transportation of boulders, cobbles, pebbles and sand mining are also stringently stopped in ordered to avoid the habitat destruction of aquatic fauna and flora including fish.

\section{CONCLUSION}

To conclude, the Canonical Correspondence Analysis (CCA) indicated that the total hardness, 
free carbon-dioxide and dissolved oxygen act as a driving variables to shape the fish community structure of Andhi Khola. The extraction and transportation of boulders, cobbles, pebbles, sand mining haphazard ongoing road development and dam construction for the irrigation without fish ladders were found to be existing threats to the fish diversity of Andhi Khola. Lepidocephalus guntea, and Heteropneustes fossilis were found to be at an alarming state for Andhi Khola. Moreover, population of Channa stewartii, Macrognathus pancalus, Garra spp. and Puntius spp. have been severely depleted and are not recorded in the present study from Andhi Khola. So, for the better protection and conservation of these species, habitat rehabilitation, and construction of fish ladders are necessarily needed. In addition, extraction and transportation of boulders, cobbles, pebbles and sand mining should also be stringently stopped in order to avoid the habitat destruction of aquatic fauna and flora including fish.

\section{ACKNOWLEDGEMENTS}

We would like to express our sincere gratitude to Prof. Dr. Tej Bahadur Thapa, Head of Central Department of Zoology, Tribhuvan University for his kind suggestions, Encouragement and academic support. We would also like to express our thanks to all the staffs of Central Department of Zoology, Tribhuvan University for their support during the completing this work. We would like to thank local fisherman for fish collection during the field work. Our special acknowledgement goes to our friends Bir Bhadur Thapa and Niraj Khadka for their suggestion and help to complete this research work.

\section{REFERENCES}

Adoni, A.D. (1985). Work book on Limnology, Department of Environment, Government of India, Pratibha Publication.

Clarke, K.R. \& Warwick, R.M. (2001). Change in Marine Communities: An Approach to Statistical Analysis and Interpretation, Plymouth, United Kingdom: PRIMER-E Ltd.

Clarke, K.R. (1993). Non parametric multivariate analyses of changes in community structure. Australian Journal of Ecology, 18: 117-143. DOI: 10.1111/j.1442-993.1993.tb00438.x.
Edds, D.R. (1986). Fishes of Kali Gnagaki/Narayani Rivers, Nepal. Journal of Natural History Museum, 10(14): 14-22.

Gauch, H.G.J. (1982). Multivariate analysis in community ecology. Cambridge: Cambridge University Press.

Gerhard, P., Maraes, R. \&Molander, S. (2003). Stream fish communities and their associations to habitat variables in a rain forest reserve in southeastern Brazil. Environmental Biology of Fisheries, 71: 321330. DOI: 10.1007/s10641-004-1260-y

Gorman, O.T. (1988). The dynamics of habitat use in a guild of Ozark minnows. Ecology of Monographs, 58(1): 1-18. DOI: 10.2307/1942631

Grossman, G.D., Ratajczak, R.E., Crawford, M. \& Freeman, M.C. (9998). Assemblage organization in stream fishes: effects of environmental variation and interspecific interactions. Ecology of Monographs, 68(3): 395-420. DOI: 10.1890/0012-9615

Harvey, B.C. \& Stewart, A.J. (1991). Fish size and habitat depth relationship in headwater streams. Oecologia, 87: 336-342.

Jayaram, K.C. (2010). The freshwater fishes of Indian region. Narendra Publishing House, Delhi, India, 614.

Kadye, W.T., Magadza, C.H.D., Moyo, N.A.G. \&Kativu, S. (2008). Stream fish assemblages in relation to environmental factors on a montane plateau. Environmental Biology of Fishes, 83: 417 428. DOI: 10.1007/s10641-008-9364-4

Limbu, J.H. \& Gupta, S. (2019a). Fish diversity of Damak and lower Terai region of Ratuwa River of Jhapa district, Nepal. International Journal of Fauna and Biological studies, 6(1): 01-04.

Limbu, J.H. \& Prasad, A. (2020). Environmental variables and fisheries diversity of the Nuwa River, Panchthar, Nepal. Scientific World, 13: 69-74. DOI: 10.3126/sw.v13i13.30542

Limbu, J.H. \& Punam, G.C. (2019b). Spatio-temporal variation of fish assemblages in Babai River of Danag district, Province No. 5, Nepal. Our Nature, 17(1): 14-25

Limbu, J.H., Acharya, G.S. \& Shrestha, O.H. (2016). A brief report on ichthyofaunal diversity of Dewmai Khola of Ilam district, Nepal. Journal of Natural History Musum, 30: 312-317. DOI: 10.3126/jnhm.v30i0.27607 
Limbu, J.H., Baniya, C.B.\& Prasad, A. (2019c). Spatiotemporal variation of fish assemblages in Ratuwa River, Ilam, Nepal. Journal of Ecology \& Natural Resources, 3(3): 000168.

Limbu, J.H., Chapagain, N., Gupta, S. \&Sunuwar, S. (2019d). Review on fish diversity of eastern Nepal. International Journal of Fisheries and Aquatic Studies,7(3): 177-181

Limbu, J.H., Prasad, A. \& Shrestha, O.H. (2018). Ichthyofaunal diversity of Bakraha River of Morang district, Nepal. International Journal of Fisheries and Aquatic Studies, 6(5): 267- 271.

Magalhaes, M.F., Batalha, D.C. \& Collares-Pereora, M.J. (2002). Gradients in stream fish assemblages across a Mediterranean landscape: contributions of environmental factors and spatial structure. Freshwater Biology, 47: 1015-1031.

Marshall, S. \& Elliott, M. (1998). Environmental influences on the fish assemblages of the Humber Estuary. U.K. Estuarine, Coastal and Shelf Science, 46: 175-184. DOI: $10.1006 /$ ecss. 1997.0268

Matthews, W.J. (1986). Fish faunal structure in an Ozark stream: Stability, persistence and a catastrophic flood. Copeia, 1986(2): 388-397. DOI: $10.2307 / 1444997$

Matthews, W.J. (1998). Patterns in freshwater fish ecology. Review in Fish Biology and Fisheries, 8: 495-497.

McGill, B.J., Enquist, B.J., Weiher, E. \& Westoby, M. (2006). Rebuilding community ecology from functional traits. Trends in Ecology and Evolution, 21: 178-185. DOI: 10.1016/j.tree.2006.02.002

Nelson J. (2007). Fishes of the World. Fourth edition. Hoboken, New Jersy, John Wiley and Sons Inc.

Oberdorff, T., Guilbert, E. \& Lucchetta, J.C. (1993). Patterns of fish species richness in the Seine River basin, France. Hydrobiologia, 259: 157-167. DOI: 10.1007/BF00006595

Oksanen, J.F.G., Blanchet, Kindt, R. \& Legendre, P.R. (2019). Vegan: Community ecology package. R package version 2: 3-1.
Oli, T.B. (2016). Fish Diversity of West Rapti River, Dang, Nepal.M.sc. Dessertation Central Department of Zoology, Tribhuvan University, Kathmandu, Nepal.

Pokharel, K.K., Basnet, K.B., Majupuria, T.C. \& Baniya, C.B. (2018). Correlation between fish assemblage structure and environmental variables of SetiGandaki River Basin, Nepal. Journal of Freshwater Ecology, 33(1): 31-43. DOI 1.0.1080/02705060.2017.1399170

R Core Team. (2019). A language and environment for statistical computing. R Foundation for Statistical Computing, Vienna, Austria. URL https://www.Rproject.org/.

Seber, G. \& Le Cren, E. (1967). Estimating Population Parameters from Catches Large Relative to the Population. Journal of Animal Ecology, 36(3): 631643. DOI: $10.2307 / 2818$

Subba, B.R., Pokharel, N. \& Pandey, M.R. (2017) Ichthyofaunal diversity of Morang district, Nepal. Our Nature, 15 (1,2): 55-67. DOI: 10.3126/on.v15il2. 18794

Talwar, P.K. \&Jhingram, A.G. (1991). Inland fishes of Indai and Adjacent countries. Oxford and IBH Publishing Co. India, (I, II):1158.

TerBraak, C.J.F. (1986) Canonical correspondence analysis-a new eigenvector technique for multivariate direct gradient analysis. Ecology. 67(5): 1167-1179. DOI: $10.2307 / 1938672$

Thapa, B. (2018). Fish diversity of Dipang Lake in the mid hill of Kaski District, Nepal. MSc. Thesis. Central Department of Zoology, Tribhuvan University, Kathmandu, Nepal.

Vlach, P., Dusek, J., Svatora, M. \& Moravec, P. (2005) Fish assemblage structure, habitat and microhabitat preference of five species in a small stream. Folia Zoologica, 54: 421-431.

Yan, Y, H.E., Shan, C.H.U., Ling, X., Xiuying, J.I.A., Anju, T.A.O. \& Yi, F.C. (2010). Spatial andtemporal variation of fish assemblages in a subtropical small stream of the Huangshan Mountain. Current Zoology, $56 \quad$ (6): 670-677. DOI: 10.1093/czoolo/56.6.670

Yu, S.L. \& Lee, T.W. (2002). Habitat preference of the stream fish, Sinogastromyzon puliensis. Zoological Studies, 41: 183-187. 